\title{
Institutional Ownership as A Predictor of Dividend Policy of Commercial Banks in Kenya
}

\author{
Dr. Rashid Simiyu Fwamba * Consolatta Nasimiyu Simiyu \\ School of business and Economics, Kibabii University, Box 1699-50200 bungoma, Kenya
}

\begin{abstract}
In Kenya the mismanagement of banks has led to banks being put under receivership and therefore denying shareholders return on their investment in form of dividends. The mismanagement has been linked to the ownership structure or share composition of the bank something that has resulted in the CBK going after assets of such banks and therefore denying shareholders return on their investment in form of dividends. Studies on ownership structure and dividend policies in Kenya have not produced conflicting results hence the need for further research with a bias in the Kenyan banking industry. The study main objective was to examine the influence of foreign ownership structure on dividend policy of commercial banks in Kenya. The study adopted the dividends signaling theory and stewardship theories. Descriptive survey research design was used to find the link between ownership structure and dividend policy. The target populations were all the 43 commercial banks licensed to operate in Kenya and all the chief finance officers employed by the 43 commercial banks. A census approach was adopted where all Chief Finance Officers of the 43 commercial banks were targeted. The study adopted primary data which was collected using a structured questionnaire. The results of the study indicated that the institutional ownership insignificant negative influence on dividend policy. The study recommends that investors consider ownership structure when making investment decision.
\end{abstract}

Key words: Dividends, Ownership, shareholders

DOI: $10.7176 /$ RJFA/10-6-14

Publication date: March $31^{\text {st }} 2019$

\subsection{INTRODUCTION}

\subsection{Background of the study}

Dividend policy is an area that many researchers have presented various theories and uncontrollable empirical evidence in both developed and developing world but the issue is still unresolved (Luvembe, Mungai, \&Simiyu 2014). The importance of dividend policy to a firm cannot be emphasized since it affects a firm's direction by determining the ability of a firm to finance its projects and hence its long term survival. Pandey (2013) defines dividend policy as the decision that a firm has to make on earnings to pay to shareholders in form of returns to their investment (dividends) or whether to retain part of the earnings.

Ownership structure is defined as the as the proportion of votes held by various shareholder in respect to their shareholding in a firm (Raji, 2012). Firms have different ownership structure including managerial ownership, institutional ownership, foreign ownership, Individual ownership among others. Different ownership comes with conflicting interests and preferences whereby as one group goes for current dividends others may prefer capital gain (Abdelwahed, 2010). Management usually face the challenge of ensuring or balancing all the needs of the investors especially when the organization has diverse ownership structure which has conflicting interests. According to Hummel (2010) investors looking to secure current income and dividends will be attracted to companies that pay dividends since it is a signal of a company financial well-being (Hummel, 2010). Therefore the firms they invest in must have an ownership structure that encourages dividend payout for them to put their money in the firm.

In India ownership structure has been shown to have impacted positively on company's dividend policy including commercial banks (Wadhawa\& Sharma, 2013). The finding of Wadhawa and Sharma, (2013) IS contradicted by an observation made on bank ownership in German. In German Elston, Hofler and Lee (2011) indicated dividend policy of banks is not influenced by ownership structure mainly because there is no tax differential between dividend payout and capital gain in the country.

In Kenya Rahab (2012) indicated that listed companies decision on paying dividends is influenced by ownership structure. It's an observation that was also supported by Kunga (2014) by finding a relationship between ownership structure and dividend policy and contradicted by Obiero (2013) who stated that factors other than ownership structure influenced dividend policy of listed companies.Mang'unyi (2011) notes that the various reforms in banking sectors motivate firms with foreign ownership to expand their operations in the country. The 
scholar further notes that foreign banks are efficient and profitable something that may ensure that the various shareholders in a firm ownership get dividends each year.

\subsection{Statement of the Problem}

Dividend policy is one of the most fundamental decisions that a firm has to make. This According to Pandey (2013) is because it involves the determination of shareholders return from their investment and therefore can be used as a tool to relay important information about the firm performance to shareholders (Pandy, 2013).In Kenya the mismanagement of banks such as imperial bank and dubaibank has led to such banks being put under receivership and therefore denying shareholders return on their investment in form of dividends. The mismanagement has been linked to the ownership structure or share composition of the bank something that has resulted in the CBK going after assets of shareholders of the bank (CBK, 2016). With such occurrences shareholders are left in dilemma when it comes to making investments in banks that have ownership structure or the shareholding that meets their preferences and interests as far as dividend policy adopted by such firms is concerned keeping in mind the conflicting preference and interests of the shareholders (Abdelwaheed, 2010).

Furthermore there is no consensus among studies that investigated ownership structure and dividend policy. Some of the studies have showed a relationship between ownership structure and dividend policy (Abdullahi, 2012; Al-nawassah, 2012; Ullah, 2012; Rahab, 2013) while others have shown no relationship (Abdelwaheed, 2014;Kunga 2014). The study seek to fill this research gap by focusing on both listed and unlisted commercial banks in Kenya. The study seeks to focus on the banking industry that has been excluded in most of the studies. The study therefore sought to fill the literature gap in this area by investigating the influence of institutional ownership structure on dividend policy of Kenya commercial banks.

\subsection{General objective}

The general objective of this study was to examine the influence of Institutional ownership structure on dividend policy of commercial banks in Kenya.

\subsection{Research Hypotheses}

$\mathrm{H}_{02}$ There is no significant relationship between institutional ownership and dividend policy of commercial banks in Kenya.

\subsection{LITERATURE REVIEW}

\subsection{Dividend signaling theory}

The theory notes that the various shareholders in a firm ownership structure can make investment decisions based on the dividend decisions made by the organization (Hong \& Nguyen, 2014). According to the scholars management has information about a firm future performance and therefore can use dividend payout to send vital information about a firms operation to the investors having shares in a firm ownership structure. In a nut shell the two scholar's notes that by paying dividends a firm shows that it's performing well and therefore investors having shares in a firm can make decisions on whether to increase or decrease the amount of shares they own in the firm ownership structure. Firer, Gilbert and Maytham (2008) observed that firms can use dividends to convey important information in the market with a firm that pay dividends sending positive image to its shareholders. According to Mirzae and Afza (2010) information asymmetry between management and shareholders can be reduced by paying dividends because by doing so the firm will send information about a firm future prospects.

Management and large institutional shareholders will tend to invest in companies that perform well hence the presence of such shareholders in the firm ownership structure may also send a signal on the firm future prospects (Ullah, Fida\& Khan, 2012). On the other hand Huda and Abdullah (2013) noted that presence of a given type of investors in the ownership structure of a firm may send a signal about the dividend policy that is likely to be adopted by the firm. The scholar's notes that institutional investors prefer low dividends and therefore the presence of institutional owners in a firm ownership structure may send a signal to shareholders and other stakeholders that the firm is likely to pay low dividends. Shukla (2014) on the other hand concludes that firms with high foreign ownership tend to pay attractive dividends and therefore the presence of foreign investors in a firm ownership structure can send a signal or be associated with the payment of high dividends.

\subsection{Stewardship Theory}

The theory was developed by Donaldson and Davis in 1991. According to Abira (2014) this theory unlike the 
agency theory argues that the decisions made by an organization will always be in the best interest of all the investors the firm ownership structure because management will also benefit when the organization succeeds (Abira, 2014). The steward management will therefore ensure that the various shareholders (institutional, managerial, foreign and individual) wealth is maximized when they perform their duties. According to the theory management who are the steward of the organization tend to be motivated when the organization performs better. According to Mokaya (2015) by the fact that the steward also benefit from the organization there is no need for shareholders having shares in the firm ownership structure to monitor their activities.

Yagit and Anil (2012) the stewardship theory ensures that the interest of the players in a firm's ownership structure is protected. Therefore the various players in the firm ownership structure can be sure that their interest will protected as far as decisions such as dividends distributions or investments is concerned. Mang'unyi (2012) notes that stewardship theory brings back the trust between various shareholders having a stake in the firm ownership structure. The theory notes that when the interests of management and others shareholders be it institutional, foreign converge the shareholders do not need to worry about the firm dividend policy or critical decisions because their interests will be protected. According to Shukla (2014) management will return fiancé to various shareholders in a firm ownership structure in order to protect their reputation. Therefore the shareholders need not to worry about dividend distribution since to protect their reputation management will always distribute dividends.Obiero (2013) argues that there can be no conflict between various shareholders in the firm ownership structure because their interests converge. The scholar further notes that the various shareholders will know the direction of the firm operations something that may ensure shareholders invest in firms that protect their interests be it dividend, distribution capital gain or even financing.

\subsection{Conceptual Framework}

\section{Independent variable}

$$
\begin{aligned}
& \text { Institutional ownership } \\
& \text { - } \quad \text { Shares held by institutional } \\
& \text { investors. } \\
& \text { - Number of institutional } \\
& \text { investors. } \\
& \text { - Institutional board } \\
& \text { representation }
\end{aligned}
$$

Figure 2.1: Conceptual Framework

\subsection{Review of Variables}

\subsubsection{Institutional Ownership}

Institutional ownership is defined by Shen (2013) as the total numbers of share held by institutional owners in an organization. The researcher carried out a study on institutional ownership and corporate policy of mutual funds listed in China for a period covering 2003 and 2011. The results of the study found that institutional ownership showed a positive relationship with dividend policy. The results concurred with that of Saif, Khan and Ali (2013) who observed that the institutional ownership and dividend policy showed a positive relationship. The researchers had measured institutional ownership as a percentage of institutional investors in a study that used secondary data that covered 5 years and targeted financial institutions including banks. However a study done by Huda (2013) found a negative significant relationship between the two variables which showed that investors prefer capital gain over dividend payouts.

In a study done on ownership structure and dividend policy Azzam (2010) found a significant negative relationship between the independent variable which was institutional ownership and the dependent variable which was measured using dividend policy and dividend policy. The researcher measured institutional ownership as proportion ofsharesheld by private and public institutions. The results were similar to those of Rahab (2012) who found a negative relationship between institutional ownership and dividend policy in a study that measured institutional ownership as a percentage of ownership by oil marketing firms. The researcher used secondary data 
that was analyzed using regression and correlation. The findings contradicted the results found by Mossadak, Fontaine and Khemakhem (2016) who found no relationship between institutional ownership and dividend policy. The three researchers measured institutional ownership using percentage of shares held by institutional owners and the analysis was done using regression method.

A research conducted by Al-Gharaib, Zurgat and Khaled (2013) on the effects of ownership structure on dividend policy of Jordanian firms found the presence of institutional ownership tend to reduce amount of dividend paid. The study was carried out on 35 firms listed in the Amman stock exchange where the partial and full adjustment model was used in the analysis of data. The findings are similar to those of Jia and Wen (2010) who argued that the presence of institutional owners will tend to reduce dividend payout after finding a negative relationship between the two variables. The researcher targeted the banking industry in the United States of America and used regression and descriptive statistics in the analysis of data.

Gill and Obradovich (2012) noted that institutional ownership has a negative influence on dividend policy in a study that targeted American firms in the service industry that are listed on the New York Stock Exchange. The study used co-relational and non-experimental research design. The findings were inconsistent with that of Ullah (2012) who targeted seventy randomly selected firms in the Karachi Stock exchange. The study used data for a period of eight years and adopted regression analysis. The results of the study found a positive relationship between institutional ownership and dividend policy and from the findings the researcher concluded that institutional owners push for more dividends payments so as to reduce amounts of cash in the hands of management which if left at their disposal may end up being misappropriated.

\subsubsection{Dividend Policy}

According to Agyei and Marforma-Yiadoma (2011) dividend is what the company distributes to shareholders at the end of each financial year in the annual general meeting. On the other hand Pandey (2013) defines dividends as the periodic payment or returns to shareholders to compensate them for investing in the company (Pandey, 2013). According to Nissim\&Ziv (2001) as cited by Uwuigibe, Jafari\&Ajayi dividend policy is the guideline used by a company when distributing dividends to shareholders.

Badu (2013) did a research dividend policy covering the period 2005-2009 for selected firms in Ghana .The study adopted panel data approach and measured dividend policy using return on asset and dividend payout strategy. Kazucu(2015) studied dividend policy of Turkish firms using panel data covering 2006-2013). In the study dividend policy was measured using dividend payout ratio. In a study done by Maniagi, Alala, Musega, Maokomba\&Egesa (2013) on dividend policy of firms listed in the NSE the researchers measured dividend policy using dividend payout and noted that dividend decisions play a very crucial role in a firm performance.

A study on dividend payout policy by Kajola, Adewumi and Oworu (2015) measured dividend policy using dividend per share. The study covered the period 2004-2013 and targeted firms listed in the Nigerian stock exchange. In another study on dividend payout, M'rabet and Boujjat (2016) measured dividend payouts using actual dividend paid. The study targeted firms listed in the Morocco stock exchange. The researchers concluded that dividend payout is very important element of a firm performance and shareholders value. On the other hand Gwaya and Ishmael (2016) noted that dividend policy adopted by a firm determine a firm future performance. The two researchers targeted public limited companies in Kenya and measured dividend policy using dividend payout ratios in a study that covered the period 2002-2011.

\subsection{METHODOLOGY}

\subsection{Research Design}

Kumar (2011) defines research design as the approach adopted by the researcher in order to obtain answers to research question. Kothari and Garg (2014) on the other hand observed that a good research design involves the procedure adopted by a researcher right from gathering of data to processing and analyzing of the same. Descriptive survey research design was usedto find the link between ownership structure and dividend policy. According to Chakrabaty (2013) survey can be grouped into questionnaire and the interview.

Quantitative approach was adopted in the study to bring out the association between the variables by clearly showing how they relate with each other hence resulting in the achievement of the research objectives. Chakrabaty (2012) notes that quantitative ensure that a study is scientific and defines quantitative method as a technique that is used to collect quantitative data or data that involve numbers. According to Kothari, (2014) quantitative data ensure clarity in research and also provide adequate information that can be replicated and 
tested hence possible to check the researcher bias.

\subsection{Population}

Population forms a basis from which sample or subjects for the study will be drawn. Population refers to entire group of people events or things of interest that a researcher wishes to investigate (Kothari, 2014).

The target population was 43 chief finance officers of the 43 commercial banks licensed to operate in Kenya as at 31 December 2015.The CFO'S will be used because they are involved in making important company decision including dividend decisions.

\subsection{Sampling and Sampling Technique}

The study adopted a census approach where by 43 CFO in all the commercial banks in Kenya 43 commercial banks targeted. The chief finance officers were purposively selected because they take part in dividend decision and also have an in-depth understanding of dividend policy adopted by the banks over the years. According to Mutai (2014) purposive sampling is when a researcher goes for people with the required information and who can provide the same. The sampling methods enable the researcher to select predetermined number of people who according to the researcher will provide information needed for the study (Kothari, 2014). Therefore the CFO's of the 43 commercial banks were selected as the key informants or respondents for the study.

\subsection{Data Collection Procedure}

The data to be used in the study was collected through administering a questionnaire to the CFOs of commercial banks. Primary data is a kind of data that has been collected for the first time and hence it's original in character (Kothari, 2014).Mutai (2014) defines a questionnaire as an instrument that has series of questions used to gather information from individuals. The CFO at the banks head office were selected as respondents due to their indepth understating of the operations of the banks and also because most of the decisions on dividend policy are made at the bank's headquarters. According to the CBK (2015) there are 43 commercial banks licensed and therefore one CFO from each bank weretargeted. Research assistants were used to administer the questionnaire to the respondents and therefore increase the response rate. The research assistant dropped the questionnaire at the bank headquarters and then picked the same from the respondents.

\subsection{Data Processing and Analysis}

The data collected in the study was guided by research objectives and research questions. Both descriptive statistics and inferential statistics were used to analyze data. The descriptive statistics was adopted in the study which mainly included percentage. Inferential statistics on the other hand measure or shows the relationship between or among variables. Inferential statistics adopted include regression and Pearson correlation. Therefore to determine the relationship between the independent variables (managerial ownership, institutional ownership, individual ownership and foreign ownership) and dependent variable (Dividend policy) inferential statistics which include correlation and regression was incorporated in the analysis of data. Data is presented in form of tables. For the purpose of retaining only indicators that are able to explain the influence of ownership structure on dividend policy factor analysis was adopted.

\subsection{Model Specification}

To determine the influence of ownership structure (managerial ownership, foreign ownership and institutional ownership) on dividend policy the regression models below will be adopted;

Multivariate Regression Model

$\mathrm{Y}=\beta \mathrm{o}+\beta_{1} \mathrm{X}_{1}+\beta_{2} \mathrm{X}_{2}+\beta_{3} \mathrm{X}_{3}+\beta_{4} \mathrm{X}_{4}+\varepsilon$

$\begin{array}{ll}\mathbf{W h e r e} ; & \\ \mathbf{Y}= & \text { Dividend policy } \\ \beta \text { o }= & \text { constant term } \\ \mathbf{X}_{\mathbf{2}}= & \text { Institutional ownership } \\ \varepsilon= & \text { error term }\end{array}$

\subsection{RESEARCH FINDINGS AND DISCUSSIONS}

\section{1: Institutional Ownership}

The study investigated the respondent's level of agreement on institutional ownership using three statements. Number of shares held by institutional owners, number of institutional owners and institutional board representation were used to operationalize institutional ownership. The respondents showed their level of agreement with the statements and the results of the respondents are as shown in table 4.1 . 


\begin{tabular}{|c|c|c|c|c|c|c|}
\hline No. & Opinion Statements & $\begin{array}{l}\text { SD } \\
\%\end{array}$ & D \% & $\mathbf{N} \%$ & $\mathbf{A} \%$ & SA \% \\
\hline 1 & $\begin{array}{l}\text { Institutional investors use their voting majority } \\
\text { power to influence their firms policy }\end{array}$ & 22.9 & 14.3 & 8.6 & 28.6 & 25.7 \\
\hline 2 & $\begin{array}{l}\text { Institutional owners finance some of the operations } \\
\text { of your organization using their financial muscle }\end{array}$ & 20.0 & 14.3 & 17.1 & 20.0 & 28.6 \\
\hline 3 & $\begin{array}{l}\text { Presence of institutional owners has led to } \\
\text { improved performance }\end{array}$ & 17.1 & 14.3 & 14.3 & 40.0 & 14.3 \\
\hline 4 & $\begin{array}{l}\text { The number of shares held by institutions has } \\
\text { increased over the years. }\end{array}$ & 22.9 & 14.3 & 8.6 & 28.6 & 25.7 \\
\hline 5 & $\begin{array}{l}\text { The number of institutions having shares in your } \\
\text { organization has grown over the years }\end{array}$ & 15.0 & 14.3 & 17.1 & 20.0 & 34.6 \\
\hline 6 & $\begin{array}{l}\text { Institutional with shares in your organization have } \\
\text { a representative in the board of directors. }\end{array}$ & 15.1 & 14.3 & 14.3 & 42.0 & 14.3 \\
\hline
\end{tabular}

Asked on whether institutional owners use their voting majority power to influence dividend policy, $22.9 \%$ of the respondents strongly disagreed, $14.3 \%$ disagreed, $8.6 \%$ were neutral, $28.6 \%$ agreed and $25.7 \%$ strongly agreed. Asked on whether number of institutional owners has increased over the years $20 \%$ of the respondents strongly disagreed, $14.3 \%$ disagreed, $17.1 \%$ were neutral, $20 \%$ agreed and $28.6 \%$ strongly agreed. Lastly asked on whether presence of institutional owners has increased performance of the organization $17.1 \%$ of the respondents strongly disagreed, $14.3 \%$ disagreed, $14.3 \%$ were neutral, $40 \%$ agreed and $14.3 \%$ strongly agreed. On the other hand $54.3 \%$ of the respondents were in agreement that shares held by institutional investors have increased over the years.

\section{2: Dividend Policy}

The study investigated the respondent's level of agreement on dividend policy using five statements. Dividend per share was used to operationalize dividend policy. The respondents showed their level of agreement with the statements and the results of the respondents are as shown in table 4.6

Table 4.2 : Dividend Policy

\begin{tabular}{lllllll}
\hline No. & Opinion Statements & $\begin{array}{l}\text { SD } \\
\text { \% }\end{array}$ & D \% & N \% & A\% & SA \% \\
\hline 1 & $\begin{array}{l}\text { The organization's dividend payment has increased } \\
\text { over the years }\end{array}$ & 34.3 & 5.7 & 8.6 & 28.6 & 22.9 \\
2 & $\begin{array}{l}\text { The organization has a higher dividend per share than } \\
\text { the industry average }\end{array}$ & 8.6 & 17.1 & 20.0 & 25.7 & 28.6 \\
3 & $\begin{array}{l}\text { The organization has a good improve of dividend per } \\
\text { share over the years }\end{array}$ & 28.6 & 8.6 & 20.0 & 22.9 & 20.0 \\
4 & $\begin{array}{l}\text { There has been an improvement in the bank dividend } \\
\text { yield over the years } \\
\text { Dividend provide a signal to investors about the } \\
\text { company performance }\end{array}$ & 17.1 & 11.4 & 25.7 & 28.6 \\
\hline
\end{tabular}

Asked on whether the organization dividend payment has increased over theyears $34.3 \%$ of the respondents strongly disagreed, $5.7 \%$ of the respondents disagreed, $8.6 \%$ were neutral, $28.6 \%$ agreed and $22.9 \%$ strongly agreed. Asked whether the organization has a higher dividend per share than the industry average $8.6 \%$ of the respondents strongly disagreed, $17.1 \%$ disagreed, 20 were neutral, $25.7 \%$ agreed and 28.6 strongly agreed. Asked on whether the organization has had an improvement in dividend per share over the years $28.6 \%$ of the 
respondents strongly disagreed, $8.6 \%$ disagreed, $20 \%$ were neutral, $22.9 \%$ agreed and $20 \%$ strongly agreed. Asked on whether the organization has had an improvement dividend yield over the years, $17.1 \%$ of the respondents strongly disagreed, $17.1 \%$ disagreed, $11.4 \%$ were neutral, $25.7 \%$ agreed and $28.6 \%$ strongly agreed. Asked on whether dividend provides a signal to investors about the company performance $20 \%$ of the respondents strongly disagreed, $8.6 \%$ disagreed, 17.1 were neutral, $34.3 \%$ agreed and 20\% strongly agreed.

\subsection{Test of Statistical Assumptions}

The study conducted tests on statistical assumptions or regression assumptions. The tested assumptions of regression includenormality, linearity, test of independence, homoscedasticity and multicolinearity. The assumptions were tested using Shapiro-wilk test, ANOVA test, Durbin Watson test, Levine test and variance inflation factor (VIF) respectively.

ANOVA was adopted to test the linear regression assumption where by non-linearity occurs when the p-value is less than 0.05 hence a p-value greater than 0.05 means that there is linear relationship. As shown in table 4.8 the p-values were greater 0.05 which means that the linear regression assumption in the linear regression was met.

Normality test was done using Shapiro-Wilk test. When the results of the test give a significance value less than 0.05 the normality assumption has been violated and when the value is greater than 0.05 the variables had a normal distribution. The results in table 4.8 shows that normality was not violated since the significance values are greater than 0.05 .

The above table shows that management ownership had a VIF value of 1.379 and tolerance value of 0.725 ; foreign ownership had a VIF value of 1.596 and tolerance value of 0.637 ; institutional ownership had a VIF value of 1.475 and tolerance value of 0.678 while individual ownership had a VIF value of 1.254 and tolerance value of 0.797 . The variables had a tolerance value which was more than 0.1 and VIF value less than 10 and therefore we can conclude that there was no multi-collinearity among the variables.

This study adopted Durbin Watson (DW) test to check that the variables in the study were not interdependence. The results as shown in the table above show that there was no interdependence among the variables because DW statistics for all the variables fall between 1.5 and 2.5 prescribed value for residual independence. To test for Homoscedasticity Levine test was adopted as shown in table 4.8. The results of the show that there was no homoscedasticity because the $\mathrm{p}$ values are greater than the 0.05 threshold set for the test. This is further supported by the results of the scatter plot in (Appendix 4: Scatter Plot) which does not clustering or systematic pattern on the scores.

Table 4.3 Assumption of Linear Regression

\begin{tabular}{|l|l|l|}
\hline & $\begin{array}{l}\text { Threshold } \\
\text { Assumption is } \\
\text { met if }\end{array}$ & $\begin{array}{l}\text { Institutional } \\
\text { Ownership }\end{array}$ \\
\hline $\begin{array}{l}\text { Normality test } \\
\text { Shapiro-Wilk }\end{array}$ & $\mathrm{p}>0.05$ & 0.149 \\
\hline $\begin{array}{l}\text { Linearity } \\
\text { ANOVA Test }\end{array}$ & $\mathrm{p}>0.05$ & 0.154 \\
\hline $\begin{array}{l}\text { Test of } \\
\text { Independence } \\
\text { Durbin- } \\
\text { Watson }\end{array}$ & $1.5-2.5$ & 1.641 \\
\hline $\begin{array}{l}\text { Homoscedasti } \\
\text { city Test } \\
\text { Levine Test }\end{array}$ & $\mathrm{p}>0.05$ & 0.331 \\
\hline $\begin{array}{l}\text { Multi- } \\
\text { collinearity } \\
\text { Test }\end{array}$ & VIF $10 \mathrm{Max}$ & $\begin{array}{l}0.678 \\
(1.475)\end{array}$ \\
\hline
\end{tabular}

\subsection{Correlation}

The study adoptedpearson correlation to determine the association between the independent and dependent and 
also check multicollinearity between the independent variables.A Pearson value greater than 0.8 shows the existance of multicollinearity.

Table 4.4 Correlation Matrix

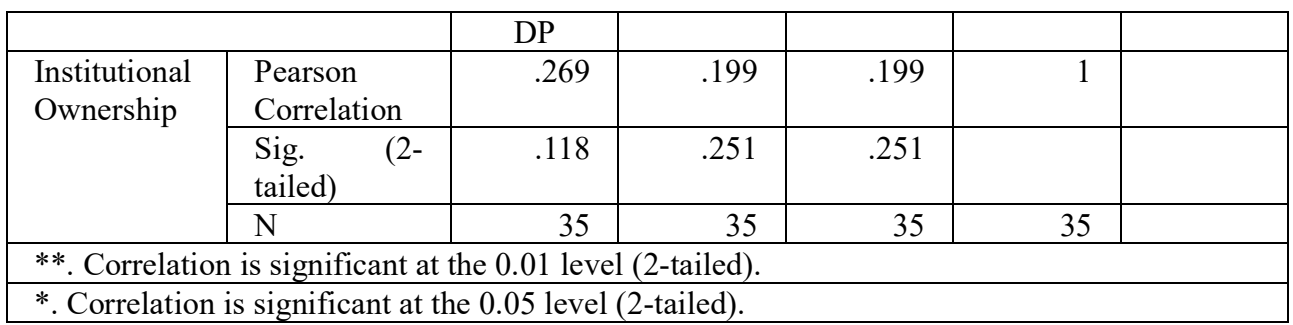

Institutional ownership and dividend policy had a positive relationship with a Pearson correlation of $\mathrm{r}=0.269$ at 0.05 confidence level. The relationship was found not to besignificant between the two variables since the Pvalue $(0.118)$ was more than 0.05 significance level set for the study. The findings were inconsistent with the findings of Rahab (2012) who found a negative relationship between institutional ownership and dividend policy but consistent with the findings of Ullah (2012) who found a positive relationship between the two variables. And noted that institutional owners push for dividends distribution as way of reducing amounts available to management that may be put into unproductive projects if let to their disposal.

Finally the results of the correlation as shown in the table above show that there was no multicollinearity between the predictor variables because the pearson correlation values between the variables was not more than 0.8. This means that the result of the regression does not give spurious coefficient.

\subsection{Regression Analysis}

\subsubsection{Institutional Ownership and Dividend Policy}

Regression analysis was used to show the relationship between institutional ownership and therefore how institutional ownership can be used to predict the dividend policy of commercial banks in Kenya. The results of the regression analysis in table 4.11 show that the coefficient of determination $\left(\mathrm{R}^{2}\right)$ is 0.073 which means that $7.3 \%$ of dividend policy is explained by institutional ownership. The results further show that changes in a firm institutional ownership will lead to change in dividend policy by 0.248 . The results further show that institutional ownership has an insignificant influence on dividend policy.

Table 4.5: Institutional Ownership and Dividend Policy

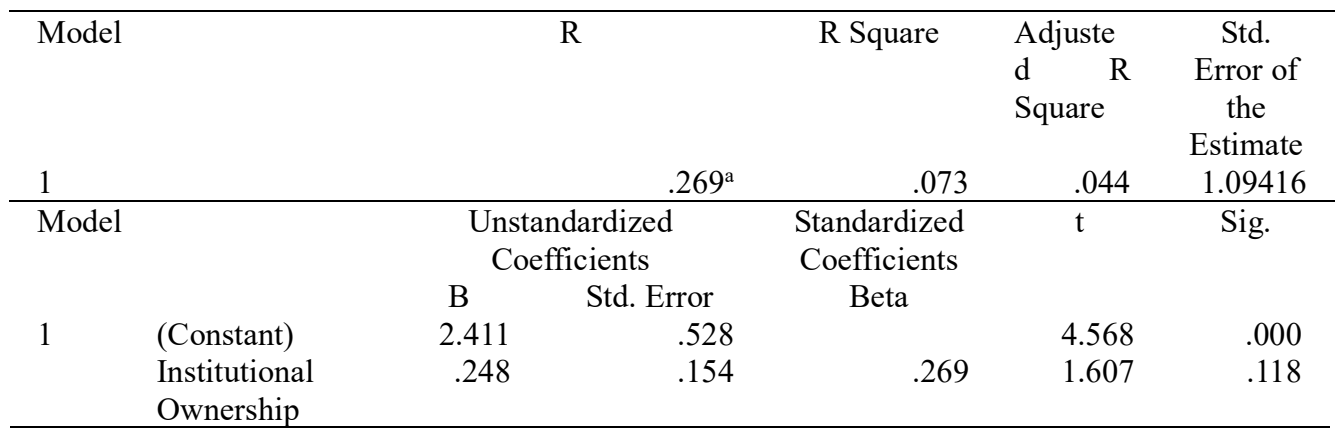

\subsubsection{Ownership Structure and Dividend Policy}

The findings showed that the coefficient of determination $\mathrm{R}^{2} \quad 0.624$ which means that $62.4 \%$ variation of dividend policy is explained by ownership structure. The remaining $37.6 \%$ is explained by other factors. The regression model will therefore be useful in making prediction since $\mathrm{R}^{2}$ is near 1 . 
Table 4.6 Ownership Structure and Dividend Policy

\begin{tabular}{|c|c|c|c|c|c|c|c|}
\hline \multicolumn{2}{|c|}{ Model } & $\mathrm{R}$ & R Square & \multicolumn{2}{|c|}{ Adjusted R Square } & \multicolumn{2}{|c|}{$\begin{array}{l}\text { Std. Error of the } \\
\text { Estimate }\end{array}$} \\
\hline \multicolumn{2}{|c|}{1} & $.790^{\mathrm{a}}$ & .624 & & .573 & & .73108 \\
\hline \multirow{2}{*}{\multicolumn{2}{|c|}{$\begin{array}{l}\text { The results of the } \\
\text { multiple } \\
\text { regressions were } \\
\text { as shown in the } \\
\text { table below: } \\
\text { Model }\end{array}$}} & \multicolumn{2}{|c|}{$\begin{array}{c}\text { Unstandardized } \\
\text { Coefficients }\end{array}$} & $\begin{array}{l}\text { Standardized } \\
\text { Coefficients }\end{array}$ & & \multirow[t]{2}{*}{$\mathrm{t}$} & \multirow[t]{2}{*}{ Sig. } \\
\hline & & $\mathrm{B}$ & Std. Error & Beta & & & \\
\hline \multirow[t]{2}{*}{1} & (Constant) & .853 & .503 & & & 1.696 & .100 \\
\hline & $\begin{array}{l}\text { Institutional } \\
\text { Ownership }\end{array}$ & -.119 & .122 & -.122 & & -.972 & .339 \\
\hline \multicolumn{8}{|c|}{$\begin{array}{l}\text { a. Predictors: (Constant), Individual Ownership, Institutional Ownership, Foreign Ownership, } \\
\text { Managerial Ownership } \\
\text { b. Dependent Variable: Dividend Policy }\end{array}$} \\
\hline
\end{tabular}

4.5.3: H01: There is no significant relationship between institutional ownership and dividend policy

The results of the study as shown in table 4.7 bellow showed no significant relationship between the two variables. That is institutional ownership and dividend policy. This because the $\mathrm{P}$ (Value) 0.118 was more than 0.005 significance level set for the study. Going by the above results we therefore accept the null alternative hypothesis. The results are similar to those of Mossadak, Fontaine and Khemakhen (2016) who did not find any relationship between institutional ownership and dividend policy

Table 4.7 ANOVA: Institutional Ownership and Dividend Policy

\begin{tabular}{llrrrrr}
\hline Model & & $\begin{array}{c}\text { Sum of } \\
\text { Squares }\end{array}$ & df & Mean Square & F & Sig. \\
\hline 1 & Regression & 3.092 & 1 & 3.092 & 2.583 & $.118^{\mathrm{b}}$ \\
& Residual & 39.507 & 33 & 1.197 & & \\
& Total & 42.599 & 34 & & & \\
\multicolumn{2}{l}{ a. Dependent Variable: Dividend Policy } & & & & \\
b. Predictors: (Constant), Institutional Ownership & & & & \\
\hline
\end{tabular}

\subsection{Discussions of Findings}

Results of the regression equation showed that institutional ownership has a negative influence on dividend policy of commercial banks licensed to operate in Kenya. The coefficient of institutional ownership in the regression equation was -0.119 . This means that an increase in institutional ownership will lead to a decrease in dividend payouts by -0.119 . The study found no significant relationship between institutional ownership and dividend policy and therefore the null hypothesis was rejected. $Y=0.853+0.574 \mathrm{X}_{1}+0.283 \mathrm{X}_{2}-0.003 \mathrm{X}_{3}-0.119 \mathrm{X}_{4}$

\subsection{SUMMARY, CONCLUSIONS AND RECOMMENDATIONS}

\section{1: Institutional Ownership and Dividend Policy}

Influence of institutional ownership on dividend policy was also considered as one of the specific objective of the study. The independent variable which was institutional ownership was measured using shares held by institutional investors, number of institutional investors and institutional board representation.

The findings of the study found that $54.3 \%$ of the respondents were in agreement when it came to institutional investors using their voting power to influence the firms policies. On number of institutions having shares increasing over the years only $48.6 \%$ of the respondents were in agreement with the statement but they were in agreement that the presence of institutional investors will tend to improve the performance of organizations. 
The found that there was a negative relationship between institutional ownership and dividend policy although the relationship wasnot significant. The pearson correlation coefficient for institutional ownership was $r=.269$. Which means Institutional ownership was found to explain only $26.9 \%$ of changes in dividend policy which is not significant and therefore the results supported the null hypothesis The beta value in the regression model was found to be -0.119 .

\subsection{Conclusion}

\subsubsection{Institutional Ownership}

From the regression and correlation results the study concluded that statistically there is no significant relationship between institutional ownership and dividend policy adopted by commercial banks. From the likert scale results most of the respondents were in agreement institutional investors may use their voting majority to influence the firm dividend policy.Majority of the respondents disagreed on the statement institutional investors finance some of the banks operations using their financial. However most of the respondents were in agreement that the number of share held by institutional investors has increased over the years. They also agreed that presence of institutional investors has led to the firms improved performance and also most of the institutional have increased share ownership in the banks over the years. On board representation majority of the repondents agreed that institutional investors have a representative on the board of directors of the banks. The study therefore concluded that despite of most of the respondents agreement on the descriptive questions, statistically as shown by the regression and correlation results there was no significant relationship between individual ownership and dividend policy aopted by commercial banks in Kenya.

\subsection{Recommendations}

It is recommended that investors who prefer companies that are not influence by other shareholders when it comes to dividend payout or retention they should look for companies with institutional owners in the company shareholding structure. This because institutional shareholders tend not to interfere with the dividend policy adopted by the management as shown by the findings of the study. Their influence on the same was found to be insignificant. However their presence in such institutions was found to improve the firm's performance. It is also recommended that investors should use the presence of institutional Investors as a sign of the firm long-term stability and good performance. These because institutional investors invest a lot of resources and have also the resources to determine the future stability of such organizations. Their presence therefore should give other investors especially the small investors' confidence in not only the organization but the industry in which the organization operates.

The study recommends to individual shareholders or investors to invest in organizations with management share ownership since they don't have any influence in the policy adopted by the company and will need someone to protect their interest and in this case management will ensure their interests is protected. The recommends that Individual shareholders should make prudent decision when investing in organizations because other shareholders will tend to override their decisions. Lastly for individual investors who prefer dividends over capital gain the study recommend that they invest in organizations that not only encourage management ownership but also foreign ownership because such organization tend to pay dividends rather than retaining profits.

\section{REFERENCES}

.Abira, A. (2014). The effect of Ownership Structure on Financial Performance of Companies Listed in the Nairobi Stock Exchange. Nairobi: University of Nairobi.

Aguenaou, S., \& Farooq, A. (2013). Dividend policy and ownership structure: Evidence from Casablanca stock exchange.GSTF Journal on Business Review, 2 (4), 116-121.

Azziz, R. (2016). The relationship between Institutional ownership and dividend policy in an emerging market . Universal Journal of Accounting and Finance, 89-95.

Bako, M. (2015). Ownership and dividend policy:An analysis of consumer goods in Nigeria. 17th International Academic Conference , 25-38. Vienna: International Academic Conference.

Elston, J., Hofler, R., \& Lee, j. (2011). Dividend policy and institutional ownership:Empirical evidence using a prospensity score matching estimator. Journal of Accounting and Finance, 11(1), 89-102.

Kilincarslan, E., \& Al-Najar.(2016). The effect of ownership structure on dividend policy: Evidence from Turkey. Emerald Insight, 16 (10), 135-161.

Kumar, R. (2011). Research Methodology, A step by step guide for beginners. New Kajola. (2015). Dividend payout and firm financial performance. International Journal of Economics, Commerce and 
Management, 3 (4), 1-13.Delhi. Sage.

Mosavi, S. (2013). Ownership Structure and Dividend Policy evidence the Tehran Stock Exchange. Academic Journal of Business Management, 7 (25), 2432-2433.

Raji, I. (2012). Effect of ownership structure on performance of firms listed in Ghana stock exchange. Accra: Kwame Nkuruma University of Science and Technology.

Salehi, S. (2010). Ownership Strcure and Dividend Payout. Asian Social Science, 6 (7), 36-42.

Shubiri, F., Taleb, G., \& Al-Zuoed, A. (2012). The relationship between Ownership Structure and Dividend Policy. Review of International Comparative Management, 13(4), 645-657.

Wadhwa, R., \& Sharma, D. (2013). Ownership structures and dividend policy : A study of Bombay stock exchange-500. Global journal of management and business studies, 3 (4), 430-434 